\title{
Use and records of child health handbook focused on growth and development
}

\author{
USO E PREENCHIMENTO DA CADERNETA DE SAÚDE DA CRIANÇA COM FOCO \\ NO CRESCIMENTO E DESENVOLVIMENTO
}

\author{
USO Y LLENADO DE LA LIBRETA DE SALUD INFANTIL CON EL FOCO EN EL \\ CRECIMIENTO Y EL DESARROLLO
}

\author{
Claudia Nery Teixeira Palombo ${ }^{1}$, Luciane Simões Duarte ${ }^{2}$, Elizabeth Fujimori ${ }^{3}$, \\ Áurea Tamami Minagawa Toriyama ${ }^{4}$
}

\begin{abstract}
Objective: To evaluate the use and records of the Child Health Handbook (CHH), especially growth and development. Method: Cross-sectional study with 358 motherchild pairs registered in 12 Primary Health Centers (PHCs) of a small municipality. Mothers were interviewed at the $\mathrm{PHC}$ from February to April 2013 using a questionnaire. Data analysis was done using WHO Anthro software, Epi Info ${ }^{\mathrm{TM}}$ and Stata. Results: Fifty-three percent of the mothers were carrying the $\mathrm{CHH}$ at the time of the interview, similar to the proportion of mothers who were instructed to bring the $\mathrm{CHH}$ to health appointments. Annotations in the $\mathrm{CHH}$ during the visits were reported by $49 \%$. The vaccination schedule was completed in $97 \%$ of the $\mathrm{CHH}$, but only $9 \%$ and $8 \%$ of the $\mathrm{CHH}$, respectively, contained growth charts and properly completed developmental milestones. Conclusion: Low rates of use and unsatisfactory record-keeping in the $\mathrm{CHH}$ reinforce the need for investment in professional training and community awareness for the $\mathrm{CHH}$ to become an effective instrument of promotion of child health.
\end{abstract}

\section{DESCRIPTORS}

Child health

Growth and development

Health Promotion

Primary Health Care

\section{RESUMO}

Objetivo: Avaliar uso e preenchimento da Caderneta de Saúde da Criança (CSC), especialmente crescimento e desenvolvimento. Método: Estudo transversal com 358 pares mãe-criança atendidos em 12 Unidades Básicas de Saúde (UBS) de município de pequeno porte. As mães foram entrevistadas nas UBS, de fevereiro a abril de 2013, com o uso de questionário. Utilizouse softwares Epi-info e Stata. Resultados: No momento da entrevista, $53 \%$ das mães portavam a CSC, proporção similar à de mães que referiram orientação para levar a CSC aos atendimentos de saúde. Anotações na CSC durante os atendimentos foram referidos por $49 \%$. Esquema vacinal estava completo em $97 \%$ das CSC, mas apenas $9 \%$ e $8 \%$ das CSC tinham, respectivamente, gráficos de crescimento e desenvolvimento adequadamente preenchidos. Conclusão: O uso e o preenchimento insatisfatório da CSC reforçam a necessidade de investimentos na capacitação dos profissionais e na sensibilização da comunidade para que a CSC se torne efetivamente um instrumento de promoção da saúde infantil.

\section{DESCRITORES}

Saúde da criança

Crescimento e desenvolvimento

Promoção da Saúde

Atenção Primária à Saúde

\section{RESUMEN}

Objetivo: Evaluar el uso y llenado de la Libreta de Salud Infantil (LSI), especialmente el crecimiento y el desarrollo. Método: Estudio transversal con 358 pares de madres e hijos matriculados en 12 Unidades Básicas de Salud (UBS) de una ciudad pequeña. Las madres fueron entrevistadas en el UBS desde febrero a abril 2013 mediante un cuestionario. Se utilizó Epi-info y software SPSS. Resultados: $53 \%$ de las madres estaban Ilevando LSI durante la entrevista, proporción similar a las madres que recibieron instrucciones para llevar el LSI a la atención de la salud. Anotaciones en LSI durante las visitas se registraron en un $49 \%$. Calendario de vacunas fue completa en el $97 \%$ de LSI, pero sólo el $9 \%$ y el $8 \%$ de LSI tenido, respectivamente, las curvas de crecimiento y desarrollos debidamente cumplimentados. Conclusión: El uso y el relleno satisfactorio de LSI refuerzan la necesidad de inversión en la formación profesional y el acercamiento a la comunidad para la LSI se convierte efectivamente en un instrumento de promoción de la salud infantil.

\author{
DESCRIPTORES \\ Salud del niño \\ Crecimiento y desarrollo \\ Promoción de la Salud \\ Atención Primaria de Salud
} ${ }^{1}$ Doctoral Student, Graduate Program in Sciences, Nursing School, University of São Paulo, São Paulo - São Paulo, Brazil. ${ }^{2}$ Master's Student, Graduate
Program in Sciences, Nursing School, University of São Paulo, São Paulo - São Paulo, Brazil. ${ }^{3}$ Associate Professor, Department of Collective Health Nursing,
Nursing School, University of São Paulo. ${ }^{4}$ Ph.D. Professor, Department of Mother-Child and Psychiatric Nursing, Nursing School, University of São Paulo,
São Paulo - São Paulo, Brazil. 


\section{INTRODUCTION}

The Child Health Handbook ( $\mathrm{CHH})$ is provided for all children born in Brazilian territory and its purpose is to gather records of the most important events related to child health. The records must start at birth, with the registering of information regarding childbirth, the baby's condition at the time of discharge, first vaccinations and exams or tests performed; and its continuity must be maintained, preferably by the professionals in the primary health centers (PHCs), where analysis of the $\mathrm{CHH}$ must be the first care provided for newborns ${ }^{(1)}$.

Nevertheless, studies concerning the use of the $\mathrm{CHH}$ are still scarce and all publications note important flaws mainly involving the quality of its records ${ }^{(2-6)}$. A review of literature published in Brazil between 2005 and 2011 concerning the factors that hinder adequate use of the $\mathrm{CHH}$ by health professionals shows as main factors lack of appreciation and knowledge regarding the $\mathrm{CHH}$ by mothers/ family members and lack of training for the professionals concerning its correct use $\mathrm{e}^{(7)}$.

It is thought that appreciation and sense of ownership of the $\mathrm{CHH}$ by mothers/family members are strongly linked to adequate use of the $\mathrm{CHH}$ by health professionals, which includes the records of the following evaluations: weight, height, nutritional and developmental status, and vaccinations and complications, as well as guidance during all appointments for the mother/family/caregiver in regard to feeding, hygiene, stimulation and vaccinations ${ }^{(8)}$.

With these considerations in mind, the objective of this study was to evaluate the use of and records in the $\mathrm{CHH}$, especially regarding growth and development, in PHCs, with the aim of promoting use of this important instrument for monitoring health, growth and development, as well as improving the child's health care.

\section{METHOD}

This observational, cross sectional study is part of a larger project titled Effects of nutritional counseling based on the Integrated Management of Childhood IIIness (IMCI) program on feeding practices, nutritional status and child development, approved by the Research Ethics Committee (Process no. 193.468). It was conducted in a small municipality in the state of São Paulo, with a population around 45,000 people, which has 12 Primary Health Centers (PHCs) where there are 13 physicians, 12 nurses, 26 nursing assistants and 32 community health agents.

The size of the sample was calculated using the Epi In$\mathrm{fo}^{\mathrm{TM}}$ software, taking into account an estimate that $50 \%$ of children show inadequate feeding practices $^{(9-12)}$; a population of 3,904 children under the age of three, registered in the PHCs; a confidence level of 95\%; and a margin of error of $5 \%$. The calculation showed the need for 350 motherchild pairs. The sampling selection was representative and proportional to the number of children registered in each PHC. From a total of 399 mothers approached in the PHCs, 35 did not agree to participate in the research and six did not meet the criteria for inclusion: three had twins, two had neurological disease and one had a child that was not her biological child. Therefore, there were 358 motherchild pairs in the study.

Data were gathered from February to April 2013, by 11 nurses and one undergraduate nursing student, properly trained. The mothers were interviewed in the PHCs with a pre-tested questionnaire. The use of the $\mathrm{CHH}$ was evaluated with the following questions: Did the mother have the $\mathrm{CHH}$ at the time of the interview? Does the mother take the $\mathrm{CHH}$ to the child's appointments? Was she instructed to take the $\mathrm{CHH}$ to health appointments? Does the mother observe health professionals making annotations in the $\mathrm{CHH}$ ? To evaluate the records, direct inspection of the $\mathrm{CHH}$ was carried out concerning the child's identification, information about childbirth, recordings of anthropometric measurements, weight and height curves, records of the chart for development and vaccination. We considered incomplete any $\mathrm{CHH}$ that was missing one of the items related to each topic, respecting age and the calendar of the child's follow-ups ${ }^{(13)}$.

For this article, the mothers were classified according to age, education level, parity and work outside of the household. The children were classified according to age, sex, weight and length at birth, attendance at day care, main caregiver and nutritional and child development status. In order to evaluate nutritional status, weight and length/height of the children were analyzed according to techniques standardized by the Brazilian Ministry of Health ${ }^{(14)}$. For children under the age of two, a digital pediatric scale (manufactured by Welmy) and a wooden anthropometer were used. For children from two to three years of age, an anthropometric platform scale (manufactured by Welmy) was used. The nutritional status was evaluated by the Body Mass Index (BMI) according to age expressed in a z-score and classified as: low weight (accentuated thinness <-3; thinness $\geq-3$ and $<-2)$, normal weight $(\geq-2$ and $<+1)$ and excessive weight (at risk of overweight $>+1$ and $<+2$; overweight $>+2$ and $<+3$; obesity $>+3)^{(15)}$. For the analysis of nutritional status the WHO Anthro software, version 3.1.0, was used. Child development was evaluated with the Development Monitoring Form, adopted by the Brazilian Ministry of Health ${ }^{(16)}$, with the categories Normal development (presence of all the signs of development in accordance with the analyzed age group) and Development alert (absence of one or more signs of development) $)^{(13)}$.

Data were inserted in a bank created using Epi Info $^{\text {TM }} 6.04$ software (Centers for Disease Control and Prevention, Atlanta, United States of America), with double digitalization for consistency check. For statistical analysis,
Use and filling of child health handbook focused on growth and development Palombo CNT, Duarte LS, FujimoriE, Toriyama ATM 
the chi-squared test and the Fisher's exact test were used with Stata software.

\section{RESULTADOS}

Table 1 presents the maternal and children's characteristics. Most mothers were over the age of 19 (87.5\%), had more than 8 years of education (64.9\%) and did not work outside the household (61.3\%). As for the children, there was a predominance of children under the age of $1(59 \%)$, males $(54.7 \%)$, and with a birth weight over 2,500 grams $(88.3 \%)$. Most did not attend daycare centers $(87.1 \%)$ and had their mothers as main caregivers (88.3\%). Underweight was present in $7.2 \%$ of the children, and excessive weight was present in almost a third.

Table 1 - Distribuição das características maternas e infantis - Município do Estado de São Paulo, 2013

\begin{tabular}{|c|c|c|}
\hline Variables $^{a}$ & $\mathbf{N}$ & $\%$ \\
\hline \multicolumn{3}{|c|}{ Maternal characteristics } \\
\hline \multicolumn{3}{|l|}{ Age (years) } \\
\hline$\leq 19$ & 43 & 12.5 \\
\hline$>19$ & 302 & 87.5 \\
\hline \multicolumn{3}{|c|}{ Education level (years in school) } \\
\hline$\leq 8$ & 124 & 35.1 \\
\hline$>8$ & 229 & 64.9 \\
\hline \multicolumn{3}{|l|}{ Parity } \\
\hline Primiparous & 153 & 42.7 \\
\hline Multiparous & 205 & 57.3 \\
\hline \multicolumn{3}{|c|}{ Works outside of the household } \\
\hline Yes & 137 & 38.7 \\
\hline No & 217 & 61.3 \\
\hline
\end{tabular}

Children's characteristics

Age (months)

$<6$

$6+12$

12 - 18

18 - 24

$24+30$

$\geq 30$

Gender

Male

Female

Birth weight (grams)

$$
<2,500
$$

$\geq 2,500$

Birth length (centimeters)

$<47$

$\geq 47$

Attends day care center (full time or part time)

Yes

No

Main caregiver (except for children who attend full-time day care centers)

Mother

Others

Nutritional status

Underweight

Normal weight

Excess weight

Child Development 
As for development, half of the children presented absence of one or more signs of development, $56.8 \%$ $(n=96)$ of them had absence of two or more signs of development (data not presented in Table 1).

It is concluded from Table 2 that only about half of the mothers had the $\mathrm{CHH}$ at the time of the interview. A proportion similar to that had been instructed to take the $\mathrm{CHH}$ to the child's appointment. The same proportion observed the professionals making annotations in the $\mathrm{CHH}$. Concerning the records, the child's identification and the information about birth were absent or incomplete in more than half of the $\mathrm{CHHs}$ analyzed. Only a third (33.8\%) of the $\mathrm{CHHs}$ presented a complete record of anthropometric measurements, and the weight and height charts were adequately recorded in less than $10 \%$ of the $\mathrm{CHHs}$, with the same for the development chart. However, the vaccination scheme was complete in $96.6 \%$ of the $\mathrm{CHHs}$ (Table 2 ).

Table 2 - Information regarding the use of and records on the CHH - Municipality of the State of São Paulo, 2013

\begin{tabular}{|c|c|c|}
\hline Variables & $\mathbf{N}$ & $\%$ \\
\hline \multicolumn{3}{|l|}{ Use of the CHH } \\
\hline The mother had the $\mathrm{CHH}$ at the time of the interview & 185 & 53.2 \\
\hline The mother reported having been instructed to take the $\mathrm{CHH}$ to health appointments & 183 & 52.0 \\
\hline The mother reported taking the $\mathrm{CHH}$ to health appointments & 271 & 76.6 \\
\hline The mother observed the health professional making annotations in the $\mathrm{CHH}$ & 173 & 49.0 \\
\hline \multicolumn{3}{|l|}{ Complete records of the $\mathrm{CHH}$ items } \\
\hline Information about birth & 84 & 47.5 \\
\hline Anthropometric measurements record sheet & 53 & 33.8 \\
\hline Height chart & 14 & 8.9 \\
\hline Weight chart & 14 & 8.9 \\
\hline Development chart & 13 & 8.3 \\
\hline Vaccination scheme & 169 & 96.6 \\
\hline
\end{tabular}

There was no information for the whole sample.

Regardless of whether or not they had a $\mathrm{CHH}$ at the time of the interview, all of the mothers were questioned about the use of this instrument by the health professionals. Having the $\mathrm{CHH}$ at the time of the interview was statistically associated with having been informed of the importance of taking the $\mathrm{CHH}$ to the child's health appointments, having being informed of the child's growth, having observed the professional making annotations in the $\mathrm{CHH}$, and the child being one year of age or less (Table 3 ).

Table 3 - Characteristics of use of the $\mathrm{CHH}$, nutritional status, development and age group of the children according to mothers who had the $\mathrm{CHH}$ at the time of the interview - Municipality of the State of São Paulo, 2013.

\begin{tabular}{|c|c|c|c|c|c|}
\hline \multirow{3}{*}{ Characteristics $^{a}$} & \multicolumn{4}{|c|}{ Mother with CHH } & \multirow{3}{*}{$\mathbf{p}^{\mathbf{b}}$} \\
\hline & \multicolumn{2}{|c|}{ Yes } & \multicolumn{2}{|c|}{ No } & \\
\hline & $\mathbf{n}$ & $\%$ & $\mathbf{n}$ & $\%$ & \\
\hline \multicolumn{6}{|c|}{ Mother instructed to take the CHH to the appointments } \\
\hline Yes & 112 & 61.9 & 67 & 41.9 & 0.000 \\
\hline No & 69 & 38.1 & 93 & 58.1 & \\
\hline \multicolumn{6}{|c|}{ Mother observed that the professional made annotations } \\
\hline Yes & 125 & 68.7 & 85 & 52.8 & 0.012 \\
\hline No & 57 & 31.3 & 76 & 47.2 & \\
\hline \multicolumn{6}{|c|}{ Mother was informed of the weight gain and height of the child } \\
\hline Yes & 161 & 88.0 & 126 & 78.8 & 0.029 \\
\hline No & 22 & 12.0 & 34 & 21.2 & \\
\hline \multicolumn{6}{|l|}{ Nutritional status } \\
\hline Underweight & 12 & 6.5 & 13 & 8.4 & 0.788 \\
\hline Normal weight & 112 & 60.9 & 93 & 60.4 & \\
\hline Excess weight & 60 & 32.6 & 48 & 31.2 & \\
\hline \multicolumn{6}{|c|}{ Adequate development } \\
\hline Normal & 84 & 51.2 & 87 & 54.0 & 0.611 \\
\hline Alert & 80 & 48.8 & 74 & 46.0 & \\
\hline \multicolumn{6}{|l|}{ Age Group } \\
\hline$\leq 1$ year of age & 122 & 66.0 & 75 & 50.7 & 0.005 \\
\hline$>1$ year of age & 63 & 34.0 & 73 & 49.3 & \\
\hline
\end{tabular}

There is no information for the whole sample.

bChi-squared test. 
No association was observed between the items being completed in the $\mathrm{CHH}$ and the nutritional status, development and age group of the children (Table 4).

\section{DISCUSSION}

The Child Health Handbook $(\mathrm{CHH})$ was created by the Brazilian Ministry of Health in 2005 to replace the Child Card (Cartão da Criança), initially promoted in the 1970s to monitor the child's growth. With the establishment of the Comprehensive Child Healthcare Program (Programa de Atenção Integral à Saúde da Criança) in 1984, the CHH became crucial for the care directed at children, considering that growth and development became the referential axis for all child health care activities ${ }^{(17)}$.

Despite of this history, only half of the mothers receiving attention at the PHC had the $\mathrm{CHH}$ at the time of the interview (53.2\%). This is a low percentage in comparison to other inquiries performed in PHCs, where $81 \%^{(18)}$ and $77 \%{ }^{(19)}$ of the interviewed mothers had the $\mathrm{CHH}$. These percentages are more similar to the percentage of mothers who reported being in the habit of taking the $\mathrm{CHH}$ to health appointments (76.6\%), but did not do so on the day of the interview.

Table 4 - Preenchimento dos itens da CSC segundo estado nutricional, desenvolvimento e faixa etária das crianças - Município do Estado de São Paulo, 2013

\begin{tabular}{|c|c|c|c|c|c|c|c|c|c|}
\hline \multirow{3}{*}{ CHH item annotation ${ }^{\mathrm{a}}$} & \multicolumn{2}{|c|}{ Nutritional statusa } & & \multicolumn{2}{|c|}{ Development $^{\mathrm{a}}$} & \multicolumn{4}{|c|}{ Age Group } \\
\hline & Adeq $^{b}$ & Inadeq $^{c}$ & \multirow[b]{2}{*}{$\mathbf{p}^{\mathbf{d}}$} & Normal & Alert & \multirow[b]{2}{*}{$\mathbf{p}^{\mathrm{d}}$} & $\leq 1$ year & $>1$ year & \multirow[b]{2}{*}{$\mathbf{p}^{\mathrm{d}}$} \\
\hline & $\begin{array}{c}n \\
(\%)\end{array}$ & $\begin{array}{c}\mathrm{n} \\
(\%)\end{array}$ & & $\begin{array}{c}n \\
(\%)\end{array}$ & $\begin{array}{c}n \\
(\%)\end{array}$ & & $\begin{array}{c}n \\
(\%)\end{array}$ & $\begin{array}{c}\mathrm{n} \\
(\%)\end{array}$ & \\
\hline \multicolumn{10}{|l|}{ Registration sheet } \\
\hline Complete & 29 & 24 & \multirow[b]{2}{*}{0.300} & 27 & 22 & \multirow[b]{2}{*}{0.160} & 36 & 17 & \multirow[b]{2}{*}{0.384} \\
\hline Incomplete & $\begin{array}{c}(30.5) \\
66 \\
(69.5)\end{array}$ & $\begin{array}{c}(39.3) \\
37 \\
(60.7)\end{array}$ & & $\begin{array}{c}(40.3) \\
40 \\
(59.7)\end{array}$ & $\begin{array}{c}(28.6) \\
55 \\
(71.4)\end{array}$ & & $\begin{array}{c}(36.7) \\
62 \\
(63.3)\end{array}$ & $\begin{array}{c}(28.8) \\
42 \\
(71.1)\end{array}$ & \\
\hline \multicolumn{10}{|l|}{ Weight Chart } \\
\hline Complete & 8 & 6 & \multirow[b]{2}{*}{0.576} & 6 & 7 & \multirow[b]{2}{*}{1.000} & 11 & 3 & \multirow[b]{2}{*}{0.255} \\
\hline Incomplete & $\begin{array}{c}(8.0) \\
92 \\
(92.0)\end{array}$ & $\begin{array}{c}(10.5) \\
51 \\
(89.5)\end{array}$ & & $\begin{array}{c}(9.1) \\
60 \\
(90.9)\end{array}$ & $\begin{array}{c}(8.7) \\
73 \\
(91.3)\end{array}$ & & $\begin{array}{c}(11.1) \\
88 \\
(88.8)\end{array}$ & $\begin{array}{c}(5.0) \\
56 \\
(94.9)\end{array}$ & \\
\hline \multicolumn{10}{|l|}{ Height chart } \\
\hline Complete & $\begin{array}{c}9 \\
(8.9)\end{array}$ & $\begin{array}{c}5 \\
(8.9)\end{array}$ & \multirow{2}{*}{1.000} & $\begin{array}{c}6 \\
(9.0)\end{array}$ & $\begin{array}{c}7 \\
(8.7)\end{array}$ & \multirow{2}{*}{1.000} & $\begin{array}{c}10 \\
(10.0)\end{array}$ & $\begin{array}{c}4 \\
(6.9)\end{array}$ & \multirow{2}{*}{0.576} \\
\hline Incomplete & $\begin{array}{c}92 \\
(91.1)\end{array}$ & $51(91.1)$ & & $\begin{array}{c}61 \\
(91.0)\end{array}$ & $\begin{array}{c}73 \\
(91.3)\end{array}$ & & $\begin{array}{c}90 \\
(90.0)\end{array}$ & $\begin{array}{c}54 \\
(93.1)\end{array}$ & \\
\hline \multicolumn{10}{|l|}{ Development chart } \\
\hline Complete & $\begin{array}{c}7 \\
(53.9)\end{array}$ & $\begin{array}{c}6 \\
(10.5)\end{array}$ & \multirow{2}{*}{0.550} & $\begin{array}{c}5 \\
(7.7)\end{array}$ & $\begin{array}{c}6 \\
(7.5)\end{array}$ & \multirow{2}{*}{1.000} & $\begin{array}{c}9 \\
(9.1)\end{array}$ & $\begin{array}{c}4 \\
(6.7)\end{array}$ & \multirow{2}{*}{0.768} \\
\hline Incomplete & $\begin{array}{c}92 \\
(64.3)\end{array}$ & $\begin{array}{c}51 \\
(89.5)\end{array}$ & & $\begin{array}{c}60 \\
(92.3)\end{array}$ & $\begin{array}{c}74 \\
(92.5)\end{array}$ & & $\begin{array}{c}89 \\
(90.8)\end{array}$ & $\begin{array}{c}55 \\
(93.2)\end{array}$ & \\
\hline
\end{tabular}

aThere was no information for the whole sample.

${ }^{\mathrm{b}}$ Adeq $=$ adequate

'Inadeq = inadequate (low weight and overweight)

'Fisher's exact test.

The percentage of mothers without the $\mathrm{CHH}$ in the health appointments at the PHCs (46.8\%) is noticeable; however, it is notable that there is an association between the age group below or equal to one year and the possession of the $\mathrm{CHH}$ by the mothers at the time of the interview. Children under the age of one are in a more vulnerable stage, when the monitoring must be more frequent. The Brazilian Ministry of Health proposes a minimum of seven medical consultations in the child's first year of life ${ }^{(13)}$. Moreover, the current vaccination schedule imposes monthly returns for children under one year old, and at least in this kind of service the mother must have the $\mathrm{CHH}$ at hand. Regardless of reason, each contact between child and health service should be seen as an opportunity for a comprehensive and resolutive evaluation of health, and the $\mathrm{CHH}$ could be even more beneficial as an instrument for this service.

Lack of appreciation and knowledge by the mothers regarding the use of the $\mathrm{CHH}$ have been reported as some of the main challenges to effective use of this instrument in health actions ${ }^{(7)}$. This may be related to historical and cultural aspects, because health actions were always handed over to the professionals; active interference by the mothers was not allowed or stimulated in the process ${ }^{(5)}$. However, health professionals also do not appreciate this important instrument for monitoring health, nutrition and child development ${ }^{(1)}$.

The weight and height charts presented a low percentage of recordings (8.9\%), confirming the results of similar studies $^{(2-4,19-20)}$. 
The low percentage of recorded weight and height charts is extremely worrying when taking into account the nutritional status of the children analyzed in this study, since the anthropometric extremes (underweight in 7.2\% and excess weight in $31.6 \%$ of the children) are over the national averages. Data from the National Demography and Child and Female Health Research (Pesquisa Nacional de Demografia e Saúde da Criança e da Mulher) showed that weight deficits in relation to height, which are signs of acute cases of malnutrition, do not go beyond $2 \%$ of the children in any region or social level of the population. Meanwhile, excess weight affects $7.4 \%$ of Brazilian children ${ }^{(12)}$. Certainly, if the $\mathrm{CHH}$ were being used adequately, it would fulfill its role in the monitoring and promotion of children's health.

A recent study showed that the themes of growth and development are analyzed in $90 \%$ of nursing consultations $^{(21)}$; however, lack of preparation by health professionals to handle the new concepts incorporated in the handbook, such as the reference curves in z-scores and the BMI-for-age chart, could justify, in part, the low percentage of growth chart records found in this study ${ }^{(7)}$.

However, a review of the literature that analyzed the practice of integrality in publications that addressed child health in basic care made it clear that inadequate use of the $\mathrm{CHH}$ is a constant, which led the authors to reinforce the need to invest in the organization of the services and in the development of the professionals, since the $\mathrm{CHH}$ is an essential instrument to guarantee integrality in childcare ${ }^{(22)}$.

The low percentage of children with recorded development charts is also noticeable, especially because half of the children analyzed presented absence of one or more signs of development, which marks an alert situation ${ }^{(13)}$.

We emphasize that the fact that the health professional is the one who records the development chart is fundamental in guiding the mothers/families in relation to the importance of observing and stimulating the child for the acquisition of new skills. This simple care action acquires a vital role in the promotion of adequate development and prevention of possible delays ${ }^{(23)}$.

Similar to other studies that analyzed $\mathrm{CHH}$ records ${ }^{(2-3)}$, data referring to vaccination were complete in almost all of the analyzed CHHs (96.6\%). This result is certainly due to the excellence of the Brazilian National Program of Immunization (Programa Nacional de Imunização), which has mobilized the entire population for more than 40 years around nationwide vaccination campaigns ${ }^{(24)}$. Moreover, the National Program of Immunization has a continued development of structures for human resources, surveillance and supervision of activities in vaccination rooms that standardize the procedures and bring stability to the actions directed at vaccination.
The lack of records or incomplete records of the other items in $\mathrm{CHHs}$ make the families think that $\mathrm{CHH}$ s have little importance in the child's monitoring; thus, they are not taken to the PHC, they are not properly kept, and they lose their character as health documents. Adequate use of $\mathrm{CHHs}$ consists of correct recording of monitoring information on the child's health and of instructing families regarding annotation and contents, enabling appreciation and appropriation of the $\mathrm{CHH}$ by families ${ }^{(3)}$. If families understood the function of this instrument, they would appreciate it more and demand its adequate recording. In addition, the lack of conscientiousness by health professionals regarding the importance of the $\mathrm{CHH}$ suggests that it is just one more form to fill out ${ }^{(3)}$.

Nutritional status and development were analyzed in this study with the objective of verifying the following hypotheses: 1 ) Children with adequate nutritional and development status would have a higher proportion of growth and/or development charts recorded, making it evident that the $\mathrm{CHH}$ fulfills its role in the monitoring and promotion of the child's health; 2) Children with inadequate nutritional and development status would have a higher proportion of growth and/or development charts recorded, showing the priority in these children's monitoring by the health professionals; and 3) Children of one year or less would have a higher proportion of the growth and/or development charts recorded, showing the priority in the monitoring of these children by the health professionals. None of these hypotheses could be confirmed because, in addition to the small number of recorded charts, the growth and development conditions and the age group of the children were not statistically associated to adequate recording of the $\mathrm{CHH}$.

Although studies of the $\mathrm{CHH}$ are scarce, all are unanimous in saying that it is necessary to promote raised awareness and educate professionals, strengthening the use of the $\mathrm{CHH}$ in an integral approach to the child's health ${ }^{(7)}$.

\section{CONCLUSION}

Considering that the evaluations were conducted in PHCs, it is a big concern the low percentage of mothers who had the $\mathrm{CHH}$ at the time of the interview and the elevated proportion of children with altered nutritional and development status .

Moreover, the poor quality of the records in the $\mathrm{CHH}$ reaffirms the importance of health professionals' qualification in relation to the correct use of the handbook. The need for investment in organization of services is also emphasized, as well as the importance of raising the awareness of the entire community so that the $\mathrm{CHH}$ truly contributes to the promotion of growth, development and improvement of children's health.
Use and filling of child health handbook focused on growth and development Palombo CNT, Duarte LS , FujimoriE, Toriyama ATM 


\section{REFERENCES}

1. Brasil. Ministério da Saúde; Secretaria de Atenção à Saúde, Departamento de Ações Programáticas Estratégicas. Área Temática de Saúde da Criança e Aleitamento Materno. Caderneta de Saúde da Criança: passaporte para a cidadania. Brasília; 2013.

2. Alves CRL, Lasmar LMLBF, Goulart LMHF, Alvim CG, Maciel GVR, Viana MRA, et al. Qualidade do preenchimento da Caderneta de Saúde da Criança e fatores associados. Cad Saúde Pública. 2009;25(3):583-95.

3. Goulart LMHF, Alves CRL, Viana MRA, Moulin ZS, Carmo GAA, Costa JGD, et al. Caderneta de Saúde da Criança: avaliação do preenchimento dos dados sobre gravidez, parto e recém-nascido. Rev Paul Pediatr. 2008;26(2):106-12.

4. Frota MA, Pordeus AMJ, Forte LB, Vieira LJES. Acompanhamento antropométrico de crianças: o ideal e o realizado. Rev Baiana Saúde Pública. 2007;31(2):212-22.

5. Vieira GO, Vieira TO, Costa MCO, Santana Netto PV, Cabral VA. Uso do cartão da criança em Feira de Santana, Bahia. Rev Bras Saúde Matern Infant. 2005;5(2):177-84.

6. Ratis CAS, Batista Filho M. Aspectos estruturais e processuais da vigilância do crescimento de menores de cinco anos em serviços públicos de saúde do Estado de Pernambuco. Rev Bras Epidemiol. 2004;7(1):44-53.

7. Abreu T, Viana L, Cunha C. Desafios na utilização da caderneta de saúde da criança: entre o real e o ideal. J Manag Prim Health Care. 2012;3(2):80-3.

8. Brasil. Ministério da Saúde; Secretaria de Atenção à Saúde, Departamento de Ações Programáticas Estratégicas. Agenda de Compromisso para a Saúde Integral da Criança e Redução da Mortalidade Infantil. Brasília; 2004.

9. Alves MN, Muniz LC, V MFA. Consumo alimentar entre crianças brasileiras de dois a cinco anos de idade: Pesquisa Nacional de Demografia e Saúde (PNDS), 2006. Ciênc Saúde Coletiva. 2013;18(11):3369-77.

10. Broilo MC, Louzada MLC, Drachler ML, Stenzel LM, Vitolo MR. Maternal perception and attitudes regarding healthcare professionals' guidelines on feeding practices in the child's first year of life. J Pediatr. 2013;89(5):485-91.

11. Garcia MT, Granado FS, Cardoso MA. Alimentação complementar e estado nutricional de crianças menores de dois anos atendidas no Programa Saúde da Família em Acrelândia, Acre, Amazônia Ocidental Brasileira. Cad Saúde Pública. 2011;27(2):305-16.
12. Brasil. Ministério da Saúde; Centro Brasileiro de Análise e Planejamento. Pesquisa Nacional de Demografia e Saúde da Criança e da Mulher - PNDS, 2006: dimensões do processo reprodutivo e da saúde da criança. Brasília; 2009.

13. Brasil. Ministério da Saúde; Secretaria de Atenção à Saúde, Departamento de Atenção Básica. Saúde da Criança: crescimento e desenvolvimento. Brasília; 2012. (Caderno da Atenção Básica, no 33).

14. Brasil. Ministério da Saúde; Secretaria de Atenção à Saúde, Departamento de Atenção Básica. Orientações para a coleta e análise de dados antropométricos em serviços de Saúde: Norma Técnica do Sistema de Vigilância Alimentar e Nutricional - SISVAN. Brasília; 2011.

15. World Health Organization (WHO). Child Growth Standards. Length/height-for-age, weight-for-age, weight-for-length, weight-for-height and body mass index-for-age: methods and development. Geneva: WHO; 2006.

16. Brasil. Ministério da Saúde; Secretaria de Atenção à Saúde, Departamento de Ações Programáticas Estratégicas. Acompanhamento do crescimento e desenvolvimento infantil. Brasília;2002.

17. Trapé CA, Fujimori E, Bertolozzi MR. O Sistema Único de Saúde e as políticas de atenção à saúde da criança. In: Fujimori E, Ohara CVS, organizadoras. Enfermagem e a saúde da criança na atenção básica. Barueri: Manole; 2009. p. 25-43.

18. Carvalho MF, Lira PIC, Romani SAM, Santos IS, Veras AACA, Batista Filho M. Acompanhamento do crescimento em crianças menores de um ano: situação dos serviços de saúde em Pernambuco, Brasil. Cad Saúde Pública. 2008;24(3):675-85.

19. Costa GD, Cotta RMM, Reis JR, Ferreira MLSM, Reis RS, Franceschini SCC. Avaliação da atenção à saúde da criança no contexto da Saúde da Família no município de Teixeiras, Minas Gerais (MG, Brasil). Ciênc Saúde Coletiva. 2011;16(7):3229-40.

20. Moreira MDS, Gaíva MAM. Acompanhamento do crescimento e desenvolvimento infantil: análise dos registros das consultas de enfermagem. Rev Pesq Cuid Fundam Online [Internet]. 2013 [citado 2014 mar. 15];5(2):3757-66. Disponível em: http://www.seer.unirio.br/index.php/cuidadofundamental/article/view/2150/pdf_774

21. Loureiro FM, Silva JANF, Quiterio MMSL, Charepe ZB. Participated observation of nursing child health consultation. Rev Esc Enferm USP [Internet]]. 2012 [cited 2014 Mar 15];46(6):1294-99. Available from: http://www.scielo.br/ pdf/reeusp/v46n6/en_02.pdf 
22. Cursino EG, Fujimori E. Integralidade como uma dimensão das práticas de atenção à saúde da criança: uma revisão bibliográfica. Rev Enferm UERJ. 2012;20(n.esp1):676-80.

23. Clendon J, Dignam D. Child health and development record book: tool for relationship building between nurse and mother. J Adv Nurs. 2010;66(5):968-77.
24. Brasil. Ministério da Saúde; Secretaria de Atenção à Saúde. Programa Nacional de Imunização: 30 anos. Brasília; 2003.

Financed by the São Paulo Research Foundation - FAPESP (Process no. 2011/509309). 